\title{
Posterior Reversible Encephalopathy Syndrome (PRES) and Takotsubo: A Heart and Brain Affair!
}

\author{
Talha Perwez ${ }^{1}$, Ahsan Wahab ${ }^{2}$, Zunirah Ahmed ${ }^{3}$, Aqsa Khan ${ }^{4}$, Zahoor Ahmed ${ }^{5}$ \\ 1. Internal Medicine, University of Alabama at Birmingham (UAB), Montgomery, USA 2. Internal Medicine Department, \\ Baptist Medical Center South, Montgomery, USA 3. Gastroenterology, Methodist Health System, Houston, USA 4. \\ Medicine, Fatima Jinnah Medical University, Lahore, PAK 5. Internal Medicine, King Edward Medical University, Mayo \\ Hospital, Lahore, PAK
}

Corresponding author: Talha Perwez, talha0097@hotmail.com

\begin{abstract}
Takotsubo cardiomyopathy (TC) is characterized by reversible left ventricle systolic dysfunction usually associated with stressors (physiological, psychological) being triggering factors. The increase in sympathetic activity, along with a subsequent surge of catecholamines, has been hypothesized as a possible etiology of TC. Posterior reversible encephalopathy syndrome (PRES), a relatively rare and recently recognized reversible clinico-radiological syndrome, is thought to share the same pathophysiology as TC. We present a case of an 83-year-old female who presented with seizures and was found to have PRES. Within three days of hospitalization, she developed takotsubo. She endorsed being under significant emotional stress that was thought to be the common culprit for both of her syndromes, i.e., PRES and TC.
\end{abstract}

Categories: Cardiology, Internal Medicine, Neurology

Keywords: pres, takotsubo cardiomyopathy, stress, catecholamines

\section{Introduction}

Takotsubo cardiomyopathy (TC), also known as stress cardiomyopathy or broken heart syndrome is specified by reversible left ventricle systolic dysfunction in the absence of influential coronary occlusions. TC mimics the acute coronary syndrome (accounts for $2 \%$ of all acute coronary syndromes), causes wall motion abnormalities, but lacks the obstructive coronary pathophysiology [1]. Many emotional or physical triggers have been proposed to induce sympathetic overactivity, causing a surge of catecholamines responsible for TC. Posterior reversible encephalopathy syndrome (PRES), a relatively rare and recently recognized reversible clinico-radiological syndrome, is characterized by acute neurologic changes, radiological evidence of focal vasogenic edema (predominantly parieto-occipital lobes), and the reversibility of clinical and/or imaging findings [2]. Many pathophysiological triggers of PRES such as uncontrolled hypertension, cytotoxic drugs, sepsis, and eclampsia are speculated to impair the blood-brain barrier, disrupt cerebral perfusion autoregulation, and lead to cerebral vascular leakage [2]. Both TC and PRES are suggested to share similar triggers or common pathophysiology [1-2]. Our case highlights the association between these two syndromes, suggesting a common etiological pathway.

Review began 01/08/2021 Review ended 02/11/2021 Published 02/20/2021

\section{(c) Copyright 2021}

Perwez et al. This is an open access article distributed under the terms of the Creative Commons Attribution License CC-BY 4.0., which permits unrestricted use, distribution, and reproduction in any medium, provided the original author and source are credited.

\section{Case Presentation}

An 83-year-old Caucasian female with a history of diabetes mellitus, hypertension, and cerebrovascular accident presented to the emergency department with new-onset generalized tonic-clonic seizures, witnessed by her daughter. Upon arrival, she had another similar seizure, after which she got obtunded and had post-ictal confusion. Her vitals were temperature: $99.2^{\circ} \mathrm{F}$, pulse: 102 beats/minute, blood pressure: 198/100 mm/Hg, respirations: 16 breaths/minute, and oxygen saturation (SpO2): 98\% on 2 liters of oxygen via nasal cannula. At the time of our evaluation (which was approximately three hours after presentation), the physical exam was normal without focal neurological deficits. Computed tomography (CT) of the brain was not significant for acute changes. Magnetic resonance imaging (MRI) (Figure 1, panel A) revealed diffuse hyperintense T2-signals in the periventricular and subcortical white matter along with two small foci of restricted diffusion consistent with punctate infarcts involving the high parietal lobe and middle left occipital lobe. The diagnosis of PRES with seizures was made. She was started on intravenous levetiracetam therapy and blood pressure was optimized. No further seizures were recorded. The patient was reported to be extremely stressed out lately due to the death of her only brother, which was thought to be contributing to elevated blood pressure and PRES. 


\section{Cureus}
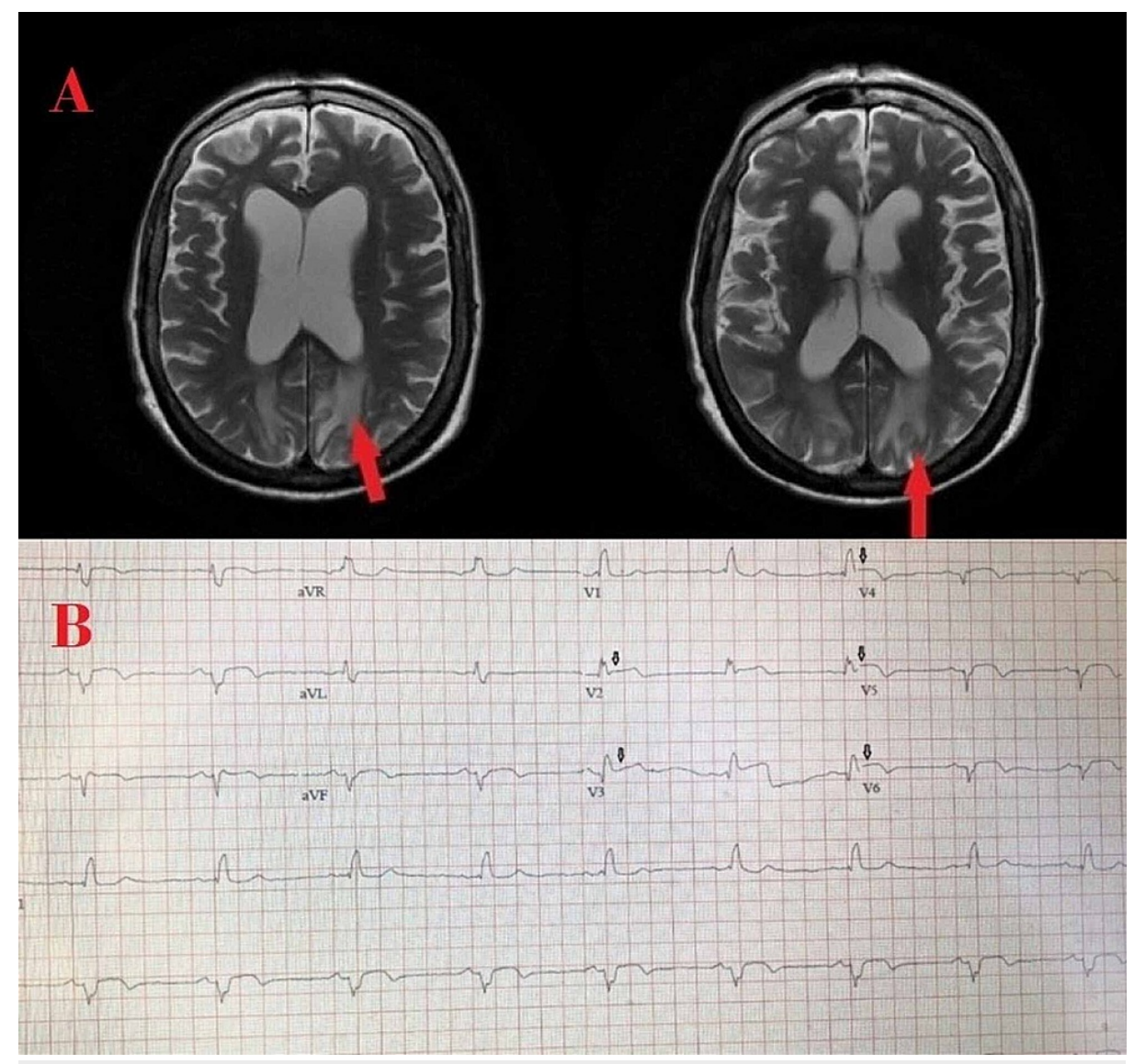

FIGURE 1: The magnetic resonance imaging (MRI) and electrocardiographic (EKG) findings of patients with posterior reversible encephalopathy syndrome (PRES) and takotsubo

A) MRI of the brain showing hyperintense T2 signals (arrows) in the periventricular and subcortical white matter of both cerebral hemispheres. B) EKG showing ST-segment elevation in leads V2-V6 (arrows).

On the third day of admission, she reported persistent nausea and gastric indigestion, which was intractable in nature requiring antiemetics and proton pump inhibitors. Troponin was found to be elevated at $2.5 \mathrm{ng} / \mathrm{ml}$ (normal reference $<0.10 \mathrm{ng} / \mathrm{ml}$ ); electrocardiogram showed ST-elevation in leads V2-V6 (Figure 1, panel B).

The echocardiogram revealed an ejection fraction of $35 \%-40 \%$ with severe apical hypokinesis (Figure 2, panel A). She underwent emergent cardiac catheterization for ST-segment elevated myocardial infarction (STEMI) and was found to have very mild coronary artery disease, unlikely to be responsible for her cardiac presentation (Figure 2, panel B), i.e., STEMI. The diagnosis of takotsubo cardiomyopathy accompanied by PRES was established. She reported immense psychological stress since the death of her brother; this was considered to be an attributor to both of her consecutive presentations. 


\section{Cureus}

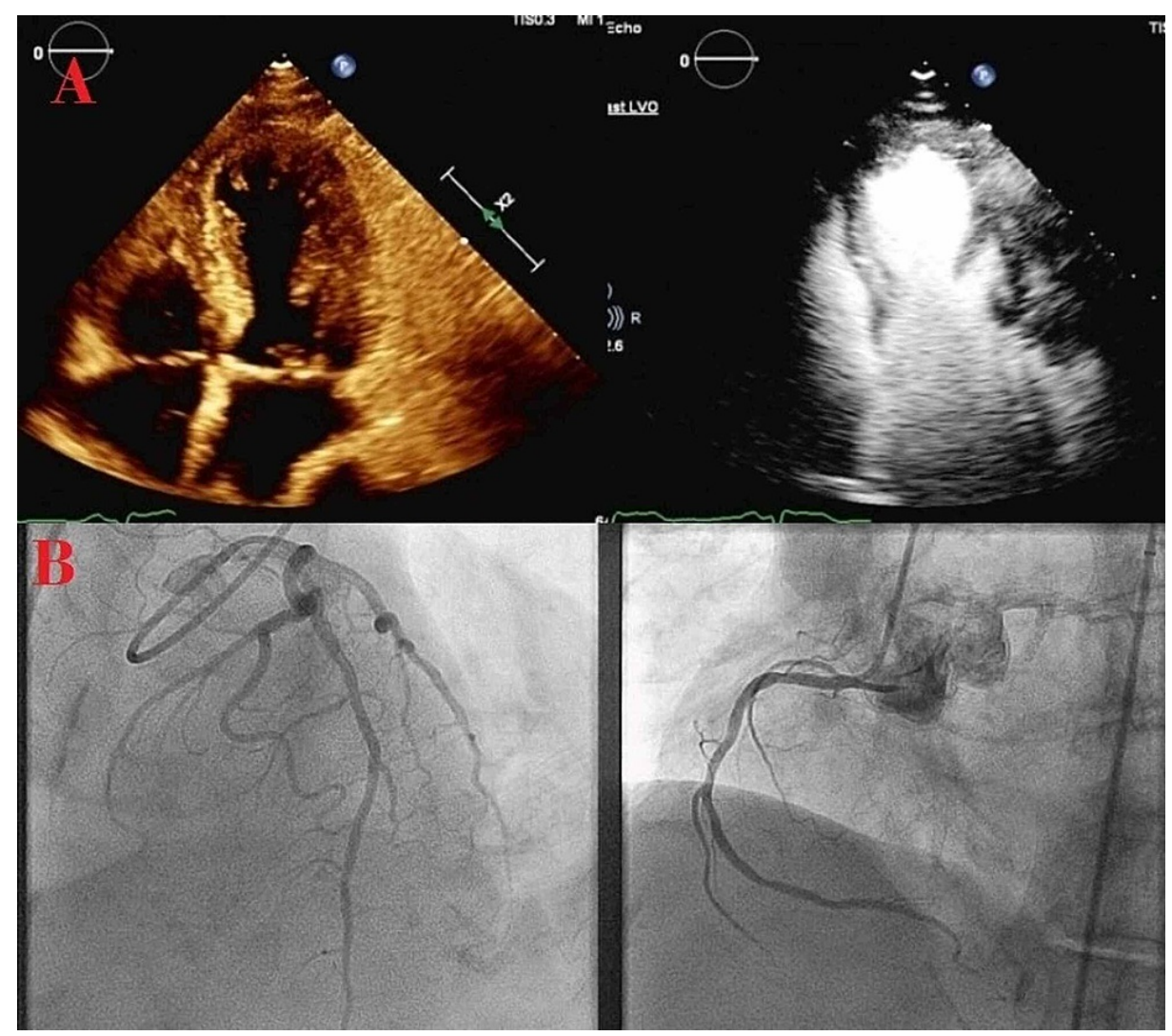

\section{FIGURE 2: Radiological findings of takotsubo}

A) Echocardiogram 2D showing severe apical hypokinesis. B) Coronary angiogram showing minimal coronary artery disease (Left anterior descending artery on the left. Right coronary artery on the right.)

\section{Discussion}

Both PRES and TC disproportionately occur in postmenopausal females, linking shared etiological grounds [1]. Pathophysiologically, PRES may be related to disordered cerebral autoregulation (neuropeptide theory) and/or endothelial dysfunction (cytotoxic theory). Other mechanisms include increased systemic blood pressure (vasogenic theory), and T-cell activation causing increased endothelial permeability (immunogenic theory) [2]. Published data on TC suggest catecholamine surge playing a role in its pathophysiology [1]. In both patients with PRES and TC, clinical and radiological findings reverse. Perhaps, this occurs due to the settling of the trigger or acclimatization of the human body to the trigger.

Several central nervous system (CNS) disorders, such as ischemic stroke, seizures, subarachnoid hemorrhage, cranial trauma, and Guillain-Barre syndrome (GBS), are associated with TC, but the association between PRES and TC is rarely reported [1]. Previously published cases of concomitant PRES and TC are described in Table 1 [3-10]. A catecholaminergic surge due to physical or emotional stressors may cause direct myocardial injury leading to stress cardiomyopathy. Similarly, increased sympathetic tone due to a stressor may contribute to PRES due to the dysregulation of cerebral blood flow. In summary, autonomic and endovascular dysfunctions may be the fundamental changes contributing to both PRES and TC. Awatsu et al. recorded hypercatecholinemia due to stress responsible for both TC and PRES [10]. Among 13 cases of concomitant PRES and TC, 12 patients were females with one case being male (see Table 1), advocating hormonal factors. Potential initiators of concomitant PRES and TC in these patients were uncontrolled hypertension, physical and emotional stressors, acute illnesses, tyrosine kinase inhibitor (Lenvatinib), and GBS. The resolution of both the syndromes was almost $100 \%$ in these cases. PRES recurred in two cases while TC recurred in one case in one retrospective review of six cases reported by Summers et al. [6].

\begin{tabular}{|c|c|c|c|c|c|c|}
\hline Author, Yr. & $\begin{array}{l}\text { Patient's } \\
\text { age and } \\
\text { gender }\end{array}$ & Trigger & PRES & TC & $\begin{array}{l}\text { Gap } \\
\text { between } \\
\text { PRES } \\
\text { and TC }\end{array}$ & Outcome \\
\hline & & & $\begin{array}{l}\text { Clinical: Seizures, AMS. } \\
\text { Radiological: MRI with }\end{array}$ & Clinical: Cardiogenic Shock. & & \\
\hline
\end{tabular}




\section{Cureus}

\begin{tabular}{|c|c|c|c|c|c|c|}
\hline $\begin{array}{l}\text { Chae et al., } \\
2018 \text { [3] }\end{array}$ & 58-YO-F & $\begin{array}{l}\text { Lenvatinib for } \\
\text { thyroid cancer }\end{array}$ & $\begin{array}{l}\text { multifocal hyperintensities } \\
\text { of frontal, parietal, and } \\
\text { occipital cortices. } \\
\text { Vasogenic edema of } \\
\text { frontal lobes. Treatment: } \\
\text { Lacosamide, } \\
\text { discontinuation of } \\
\text { lenvatinib. }\end{array}$ & $\begin{array}{l}\text { Radiological: Drop in EF on Echo } \\
\text { from } 62 \% \text { to } 36 \% \text {, Hypokinesis of } \\
\text { basal to mid-ventricular segments, } \\
\text { and hyperdynamic apical segments. } \\
\text { Treatment: vasopressor for shock, } \\
\text { ACE inhibitor, and beta-blocker for } \\
\text { ventricular dysfunction. }\end{array}$ & $\begin{array}{l}\text { Within } 2 \\
\text { days }\end{array}$ & $\begin{array}{l}\text { PRES: Near- } \\
\text { complete resolution } \\
\text { of MRI findings TC: } \\
\text { Recovery of EF. } \\
\text { Survival: Death due } \\
\text { to cancer }\end{array}$ \\
\hline $\begin{array}{l}\text { Grımaldı et } \\
\text { al., } 2017 \text { [4] }\end{array}$ & 69-YO-M & Not reported & $\begin{array}{l}\text { Clinical: Left-sided } \\
\text { hemiparesis, coma, } \\
\text { seizures, elevated BP. } \\
\text { Radiological: MRI with } \\
\text { cortical, and subcortical } \\
\text { vasogenic edema and } \\
\text { posterior predominance. } \\
\text { Cerebral angio showed no } \\
\text { occlusions. }\end{array}$ & $\begin{array}{l}\text { Clinical: comatose state, elevated } \\
\text { troponin, transient LBBB. } \\
\text { Radiological: Echo with apical } \\
\text { akinesis and altered EF. Coronary } \\
\text { Angio without stenosis but mid and } \\
\text { apical hypokinesia. }\end{array}$ & $\begin{array}{l}\text { Within } 3 \\
\text { days }\end{array}$ & $\begin{array}{l}\text { PRES: Resolution } \\
\text { of vasogenic } \\
\text { edema. TC: } \\
\text { Normalization of } \\
\text { EF, hypokinesis. } \\
\text { Survival: Recovery } \\
\text { in } 3 \text { months }\end{array}$ \\
\hline $\begin{array}{l}\text { Yadav et al., } \\
2015 \text { [5] }\end{array}$ & 60-YO-F & $\begin{array}{l}\text { Emotional } \\
\text { stress }\end{array}$ & $\begin{array}{l}\text { Clinical: vision loss, } \\
\text { headache, } \\
\text { nausea/vomiting, elevated } \\
\text { BP Radiological: MRI with } \\
\text { vasogenic edema of } \\
\text { bilateral frontal and } \\
\text { parietal lobes. MRA } \\
\text { unremarkable. Treatment: } \\
\text { strict control of BP }\end{array}$ & $\begin{array}{l}\text { Clinical: Chest discomfort, elevated } \\
\text { troponin, inferoposterior ST- } \\
\text { elevation on EKG. Radiological: } \\
\text { Echo with decreased EF and } \\
\text { hypokinesis of basal anterolateral } \\
\text { and inferolateral. Cardiac Cath with } \\
\text { akinesis of basal, mid anterior, and } \\
\text { inferior wall without coronary } \\
\text { obstruction. }\end{array}$ & $\begin{array}{l}\text { Within } 1- \\
2 \text { days }\end{array}$ & $\begin{array}{l}\text { PRES: Resolution } \\
\text { of symptoms. TC: } \\
\text { Resolution of } \\
\text { STEMI. No fibrosis } \\
\text { or infarction of } \\
\text { cardiac MRI. } \\
\text { Survival: Recovery } \\
\text { in few days. }\end{array}$ \\
\hline $\begin{array}{l}\text { Summers et } \\
\text { al., } 2012 \text { [6] }\end{array}$ & $\begin{array}{l}6 \\
\text { females, } \\
\text { mean } \\
\text { age of } \\
64\end{array}$ & $\begin{array}{l}\text { Physical } \\
\text { stressors, } \\
\text { acute illnesses }\end{array}$ & $\begin{array}{l}\text { Clinical: AMS, headache, } \\
\text { seizures, visual changes. } \\
\text { Radiological: vasogenic } \\
\text { edema predominantly in } \\
\text { the posterior circulation. } \\
\text { Treatment: correct } \\
\text { underlying cause, anti- } \\
\text { seizures, control of BP. }\end{array}$ & $\begin{array}{l}\text { Clinical: Dyspnea, chest pain, } \\
\text { elevated troponin, ST-T wave } \\
\text { changes on EKG. Radiological: } \\
\text { Reduced EF and wall motion } \\
\text { abnormalities on Echo. Treatment: } \\
\text { Control BP, treat the underlying } \\
\text { cause. }\end{array}$ & $\begin{array}{l}\text { Within } 1 \\
\text { day to } 9 \\
\text { months }\end{array}$ & $\begin{array}{l}\text { PRES: } \\
\text { Improvement or } \\
\text { near-complete } \\
\text { resolution } 1 \text { patient } \\
\text { with recurrence. } \\
\text { TC: Resolution of } \\
\text { low EF and reversal } \\
\text { of wall motion } \\
\text { abnormalities in all. } \\
2 \text { with recurrence. } \\
\text { Survival: All } \\
\text { patients recovered. }\end{array}$ \\
\hline $\begin{array}{l}\text { Fugate et al., } \\
2009[7]\end{array}$ & 82-YO-F & GBS & $\begin{array}{l}\text { Clinical: uncontrolled BP, } \\
\text { status epilepticus. } \\
\text { Radiological: MRI with } \\
\text { bilateral hyperintensities in } \\
\text { occipital lobes and } \\
\text { thalamus along with } \\
\text { vasogenic edema. } \\
\text { Treatment: Correct } \\
\text { underlying cause, anti- } \\
\text { seizures. }\end{array}$ & $\begin{array}{l}\text { Clinical: Dyspnea, Hypotension. ST } \\
\text { elevation. Radiological: Apical } \\
\text { akinesis and EF of } 30 \% \text { on echo. } \\
\text { Cardiac Cath without coronary } \\
\text { stenosis. }\end{array}$ & $\begin{array}{l}\text { Within } 1 \\
\text { day }\end{array}$ & $\begin{array}{l}\text { PRES: Near } \\
\text { complete resolution } \\
\text { in } 2 \text { weeks. TC: } \\
\text { Improvement in EF } \\
\text { in } 2 \text { weeks. } \\
\text { Survival: Complete } \\
\text { recovery. }\end{array}$ \\
\hline $\begin{array}{l}\text { Papanikolaou } \\
\text { et al., } 2009 \\
\text { [8] }\end{array}$ & 47-YO-F & $\begin{array}{l}\text { Uncontrolled } \\
\text { BP due to renal } \\
\text { failure }\end{array}$ & $\begin{array}{l}\text { Clinical: Headaches, vision } \\
\text { loss, and seizures. } \\
\text { Radiological: MRI with } \\
\text { white matter changes in } \\
\text { the parietooccipital } \\
\text { regions bilaterally. } \\
\text { Treatment: Control BP, } \\
\text { antiseizure. }\end{array}$ & $\begin{array}{l}\text { Clinical: Cardiogenic shock, } \\
\text { pulmonary edema, EKG with T-wave } \\
\text { inversion in inferolateral leads. } \\
\text { Radiological: Global left ventricular } \\
\text { hypokinesis on echo. Treatment: } \\
\text { vasopressors. }\end{array}$ & $\begin{array}{l}\text { Few } \\
\text { hours. }\end{array}$ & $\begin{array}{l}\text { Survival: Resolution } \\
\text { of the cardiac and } \\
\text { neurological } \\
\text { condition. }\end{array}$ \\
\hline $\begin{array}{l}\text { Banuelos et } \\
\text { al., } 2008 \text { [9] }\end{array}$ & 56-YO-F & $\begin{array}{l}\text { Uncontrolled } \\
\text { BP }\end{array}$ & $\begin{array}{l}\text { Clinical: Headache, } \\
\text { seizures, nausea, vomiting. } \\
\text { Radiological: MRI with } \\
\text { multifocal bilateral cortical } \\
\text { and subcortical }\end{array}$ & $\begin{array}{l}\text { Clinical: Elevated troponins, } \\
\text { nonspecific T-wave abnormalities. } \\
\text { Radiological: Echo with EF of } 40 \% \\
\text { and hypokinesis of the apical wall } \\
\text { region with EF } 40 \% \text {. Cardiac Cath }\end{array}$ & $\begin{array}{l}\text { Within } 3 \\
\text { days }\end{array}$ & $\begin{array}{l}\text { PRES: } \\
\text { Normalization of EF } \\
\text { and reversal of wall } \\
\text { motion } \\
\text { abnormalities at } 3 \\
\text { days TC: }\end{array}$ \\
\hline
\end{tabular}




\section{Cureus}

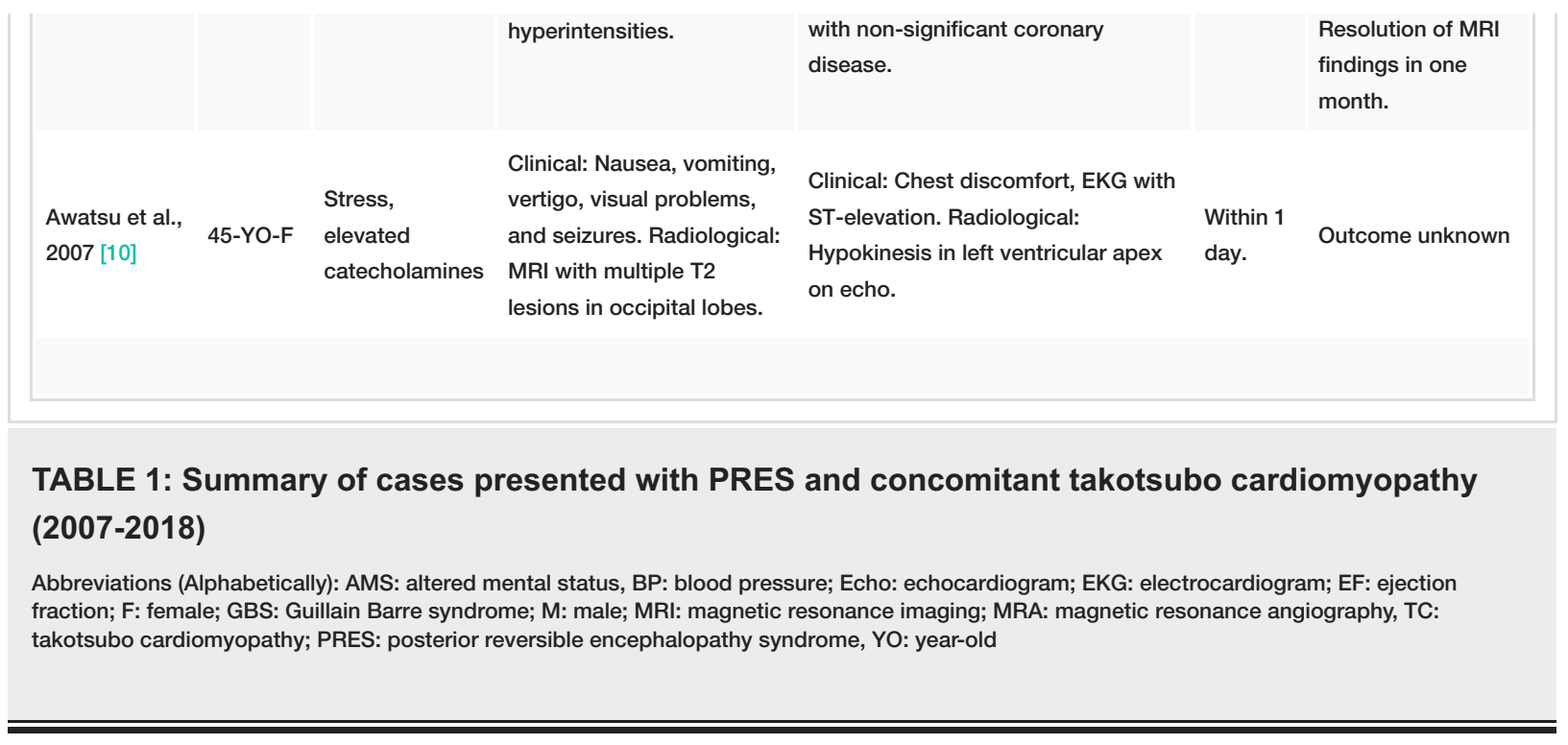

Conclusions

The presentation of these two entities in a single patient is rare. Our case further validates the theory of "heart and brain connection," with emotional stress leading to a catecholamine surge - potentially a shared mechanism connecting the two disorders. It is highly likely that both of these syndromes may have shared pathophysiology and common precipitating factors that need to be further explored and determined.

\section{Additional Information}

\section{Disclosures}

Human subjects: Consent was obtained or waived by all participants in this study. Conflicts of interest: In compliance with the ICMJE uniform disclosure form, all authors declare the following: Payment/services info: All authors have declared that no financial support was received from any organization for the submitted work. Financial relationships: All authors have declared that they have no financial relationships at present or within the previous three years with any organizations that might have an interest in the submitted work. Other relationships: All authors have declared that there are no other relationships or activities that could appear to have influenced the submitted work.

\section{References}

1. Templin C, Ghadri JR, Diekmann J, et al.: Clinical features and outcomes of takotsubo (stress) cardiomyopathy. N Engl J Med. 2015, 3:929-938. 10.1056/NEJMoa1406761

2. Fugate JE, Claassen DO, Cloft HJ, Kallmes DF, Kozak OS, Rabinstein AA: Posterior reversible encephalopathy syndrome: associated clinical and radiologic findings. Mayo Clin Proc. 2010, 85:427-432. 10.4065/mcp.2009.0590

3. Chae YK, Chiec L, Adney SK, et al.: Posterior reversible encephalopathy syndrome and takotsubo cardiomyopathy associated with lenvatinib therapy for thyroid cancer: a case report and review. Oncotarget. 2018, 9:28281-28289. 10.18632/oncotarget.25606

4. Grimaldi S, Doche E, Rey C, et al.: Association of posterior reversible encephalopathy syndrome and transient apical ballooning syndrome (takotsubo): first case report of a man and review of the literature. Case Rep Neurol. 2017, 9:173-178. 10.1159/000474933

5. Yadav D, Garg L, Narwal P, Ladkany R, Franey L: Concomitant takotsubo cardiomyopathy with PRES syndrome: a coincidence or a real heart-brain connection?. J Cardiol Cases. 2015, 12:48-51. 10.1016/j.jccase.2015.04.005

6. Summers MR, Madhavan M, Chokka RG, Rabinstein AA, Prasad A: Coincidence of apical ballooning syndrome (tako-tsubo/stress cardiomyopathy) and posterior reversible encephalopathy syndrome: potential common substrate and pathophysiology? J Card Fail. 2012, 18:120-125. 10.1016/j.cardfail.2011.10.012

7. Fugate JE, Wijdicks EF, Kumar G, Rabinstein AA: One thing leads to another: GBS complicated by PRES and takotsubo cardiomyopathy. Neurocrit Care. 2009, 11:395. 10.1007/s12028-009-9279-8

8. Papanikolaou J, Tsirantonaki M, Koukoulitsios G, Papageorgiou D, Mandila C, Karakitsos D, Karabinis A: Reversible posterior leukoencephalopathy syndrome and takotsubo cardiomyopathy: the role of echocardiographic monitoring in the ICU. Hellenic J Cardiol. 2009, 50:436-468.

9. Banuelos PA, Temes R, Lee VH: Neurogenic stunned myocardium associated with reversible posterior leukoencephalopathy syndrome. Neurocrit Care. 2008, 9:108-111. 10.1007/s12028-008-9103-X

10. Awatsu Y, Morita M, Nakano I: A case of posterior reversible encephalopathy syndrome complicated by takotsubo cardiomyopathy and hypercatecholaminemia. Auton Neurosci. 2007, 135:144.

10.1016/j.autneu.2007.06.252 